\title{
Seasonal variation in ethoxyresorufin $O$-deethylase (EROD) activity in European eels Anguilla anguilla and flounders Pleuronectes flesus from the Severn Estuary and Bristol Channel
}

\author{
J. M. Rotchell ${ }^{1}$, D. J. Bird ${ }^{2, *}$, L. C. Newton ${ }^{2}$ \\ ${ }^{1}$ Department of Biological Sciences, Johns Hopkins University, 3400 North Charles Street, Baltimore, Maryland 21113, USA \\ ${ }^{2}$ Faculty of Applied Sciences, University of the West of England, Bristol BS16 1QY, United Kingdom
}

\begin{abstract}
The Severn Estuary and Bristol Channel form the largest estuary in the UK. The estuary receives organic contaminants, including polyaromatic hydrocarbons (PAHs) and polychlorinated biphenyls (PCBs) from diverse sources. Although hepatic ethoxyresorufin $O$-deethylase (EROD) activity has been widely used as a biomarker for organic contamination in fish, its activity can be affected by a number of seasonal and environmental factors. We therefore measured EROD activity in the liver of European eels Anguilla anguilla and flounders Pleuronectes flesus, 2 abundant species in the Severn Estuary. Fish were collected from the water-intake screens of 2 nuclear power stations, located at Oldbury-upon-Severn and Hinkley Point, every 2 to 4 wk between March 1996 and February 1998. EROD activity in eels showed pronounced seasonal variation. Maximum activity $\left(656\right.$ to $820 \mathrm{pmol} \mathrm{min}^{-1}$ $\mathrm{mg}^{-1}$ protein) occurred in the warmest summer months and lowest activity (117 to $128 \mathrm{pmol} \mathrm{min} \mathrm{mig}^{-1}$ protein) in the coldest winter months. EROD activity was also elevated during the summer in flounders (470 to $650 \mathrm{pmol} \mathrm{min} \mathrm{mg}^{-1}$ protein) but the highest EROD activities (up to $1546 \mathrm{pmol} \mathrm{min}^{-1} \mathrm{mg}^{-1}$ protein) occurred in the winter/spring when spawning occurs in this species. However, these elevations occurred even in immature $1+$ and $2+$ flounders, suggesting that some other physiologicalendocrinological cycles relating to day length may also be involved. Intraperitoneal injection of benzo[a]pyrene resulted in increased EROD activity in both species to levels similar to the maximum observed in fish from the field. The results confirm that pronounced variation in EROD activity is associated with season and age in eels and flounders and these factors should be considered when employing this biomarker in the field.
\end{abstract}

KEY WORDS: EROD in eels and flounders · Severn Estuary · Fish biomonitoring · Seasonal variation . Estuarine contamination

\section{INTRODUCTION}

In fish and all other vertebrates that have been examined, exposure to environmental xenobiotics, particularly polyaromatic hydrocarbons (PAHs) and polychlorinated biphenyls (PCBs), induces the production of specific enzymes that transform these compounds into more water-soluble, and therefore more excretable, metabolites (Goksøyr \& Förlin 1992, Livingstone 1993). One family of enzymes in particular,

·Corresponding author. E-mail: david.bird@uwe.ac.uk the cytochrome P4501A isoenzymes (CYP1A), are rapidly induced following exposure to PAHs, PCBs and related compounds (Stegeman \& Hahn 1994). Their action can be conveniently determined as ethoxyresorufin $O$-deethylase (EROD) activity by using a highly specific model substrate, ethoxyresorufin (Burke \& Mayer 1974).

EROD activity has been used as one of a suite of biomarkers to measure CYP1A induction triggered by environmental contamination and it has been employed to monitor sub-lethal effects of oil spills (George et al. 1995) and other forms of contamination 
in marine (Narbonne et al. 1991) and estuarine environments (Sulaiman et al. 1991, Murphy \& Gooch 1997). It has also proved to be a useful biomarker in freshwater ecosystems (Curtis et al. 1993), particularly for detecting the biological effects of pulp mill effluents (Lindström-Seppä et al. 1992, Förlin et al. 1995, Huuskonen \& Lindström-Seppä 1995).

Demersal fish species are frequently chosen for environmental monitoring because of their close association with sediments which often contain high concentrations of pollutants compared with levels in the overlying water column (Law \& Biscaya 1994). There is considerable information available for dab Limanda limanda (Lange et al. 1992, Saborowski et al. 1996), plaice Pleuronectes platessa; (Eggens et al. 1995, Eggens et al. 1996a) and flounder Pleuronectes flesus; (Eggens et al. 1995, 1996a,b, Goksøyr et al. 1996, Hylland et al. 1996). The European eel Anguilla anguilla has also been used in biomonitoring programmes (de Boer \& Hagel 1994, Fenet et al. 1996, van der Oost et al. 1996, Weatherley et al. 1997). This species has the advantages of being relatively long-lived, sedentary and euryhaline (Fenet et al. 1996).

Although EROD activity has proved to be a useful tool for monitoring sub-lethal effects of environmental contamination, there are some factors that limit its use. Seasonal, temperature and sexual cycles have all been shown to affect enzyme activity (Collier et al.
1995, Sleiderink et al. 1995, Saborowski et al. 1996) and differences between the EROD activity of male and female fish have frequently been observed (Lindström-Seppä 1985, Eggens et al. 1996b, Vandermeulen \& Mossman 1996). However, few studies, other than a recent report by Hylland et al. (1998), have investigated seasonal variation in EROD activity in any detail.

The Severn Estuary and Bristol Channel form the largest estuary in the United Kingdom (Fig. 1) and it receives effluent from a large number of industrial and urban sources (Anonymous 1997). The strong currents and high tides ensure that these contaminants are rapidly mixed and dispersed within the system. A recent survey of $15 \mathrm{PAHs}$ in water from sites in the Bristol Channel suggest that PAH contamination is comparable to other industrialised estuaries in the United Kingdom (Law et al. 1997) but there are no published data on biomarkers in the fish from the Severn Estuary.

In order to determine the extent of natural variation in CYP1A activity, we investigated base-line responses in eels and flounders collected from the Severn Estuary and Bristol Channel, by measuring hepatic EROD activity over a 2 yr period. An exposure experiment was also conducted in order to provide reference values for non-stressed and contaminant-induced EROD values in these fish.

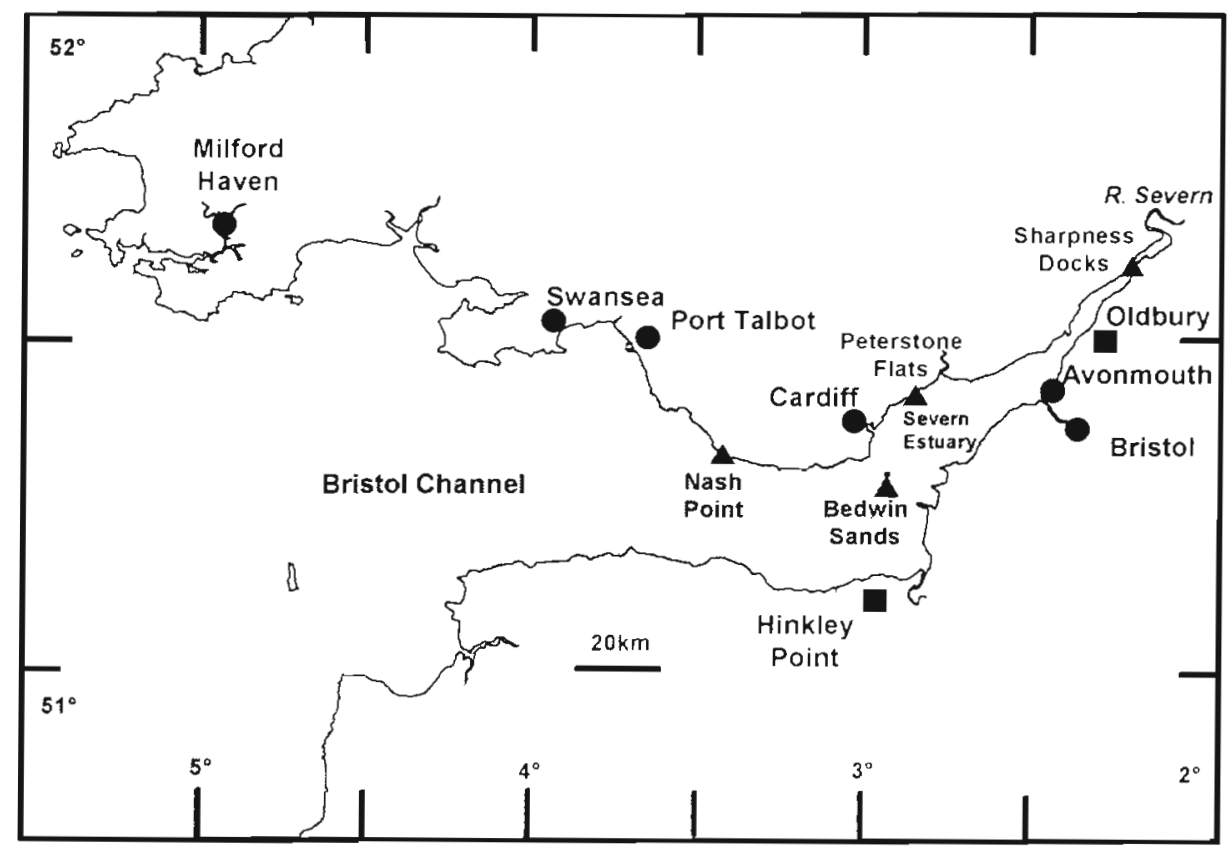

Fig. 1. The Severn Estuary and Bristol Channel. : important sites of industrial activity. $\mathbf{\square}$ : location of the nuclear power stations at Oldbury-upon-Severn and at Hinkley Point where fish were collected. $\mathbf{\Lambda}$ : sites where sediment contamination is monitored in the estuary as part of a National Monitoring Programme 


\section{MATERIALS AND METHODS}

298 European eels Anguilla anguilla and 168 European flounders Pleuronectes flesus were obtained from the water-intake screens at Oldbury-upon-Severn power station (Fig. 1). 88 flounders were also collected from water-intake screens at Hinkley Point power station (Fig. 1). Fish were obtained approximately every 2 wk from the former and every month from the latter between March 1996 and February 1998. Power station staff provided the mean daily temperatures of the cooling water entering the power stations and water conductivity was recorded using a conductivity meter (Philips model PW 9505).

Fish were brought to the laboratory alive in oxygenated water. They were killed with an overdose of benzocaine (100 $\left.\mathrm{mg} \mathrm{l}^{-1}\right)$ after recording standard length and wet weight. The liver was removed and weighed to the nearest $0.01 \mathrm{~g}$, then divided longitudinally. A 100 to $200 \mathrm{mg}$ sub-sample was rinsed in deionised water, frozen in liquid nitrogen and stored at $-80^{\circ} \mathrm{C}$. Otoliths were removed and used to determine the age of each fish (Christensen 1964, Moriarty 1973). For flounders, ages were confirmed by comparison with year classes deduced from length-frequency distributions.

Fish collected in April 1997 were maintained in 2501 tanks containing filtered estuary water at $12^{\circ} \mathrm{C}$ for $5 \mathrm{wk}$. They were then given a single intra-peritoneal injection of benzola]pyrene $(\mathrm{B}[\mathrm{a}] \mathrm{P})$ dissolved in olive oil to give a final dose of $100 \mathrm{mg} \mathrm{B}[\mathrm{a}] \mathrm{P} \mathrm{kg}^{-1}$ fish. Control fish were injected with an equivalent volume of olive oil. All fish were killed $5 \mathrm{~d}$ later and their livers were removed and frozen.

EROD activity was determined in liver S9 fractions prepared using the method of Stagg et al. (1995). All procedures were performed on ice or in a cold room at $4^{\circ} \mathrm{C}$. A known weight of liver $(100$ to $200 \mathrm{mg}$ ) was minced with small scissors and placed in a glass homogeniser tube. A $100 \mathrm{mM}$ phosphate buffer, $\mathrm{pH}$ 7.5, containing $1 \mathrm{mM}$ EDTA, $1 \mathrm{mM}$ dithiothreitol (DTT), $150 \mathrm{mM} \mathrm{KCl}$ and $15 \% \mathrm{v} / \mathrm{v}$ glycerol was added to the chopped tissue using $5 \mu \mathrm{l}$ of buffer for each $\mathrm{mg}$ of tissue. The samples were homogenised for $2 \mathrm{~min}$ then centrifuged for $30 \mathrm{~min}$ at $9000 \times \mathrm{g}$. The supernatant was stored at $-80^{\circ} \mathrm{C}$. The $\mathrm{S} 9$ protein content was determined using a commercial kit based on a Lowry determination (Sigma, Cat. No. BCA-1) with bovine serum albumin as the protein standard.

The livers from the $\mathrm{B}[\mathrm{a}] \mathrm{P}$-exposed fish were used to optimise the conditions for the EROD assay. Maximum EROD activity was obtained in both eel and flounder livers with final concentrations of $2 \mathrm{mM} 7$-ethoxyresorufin and $0.75 \mathrm{mM} \mathrm{NADPH}$ (Sigma). Resorufin standard, diluted to a final concentration of $30 \mathrm{pmol}$, was used to calibrate each run. All other solutions and assay conditions are described in Stagg et al. (1995). Eel and flounder livers were assayed in duplicate in random order and EROD activity was expressed as pmol resorufin $\mathrm{min}^{-1} \mathrm{mg}^{-1}$ protein. Samples of an S9 preparation from B[a]P-exposed salmon, kindly supplied by Dr R. Stagg (SOAEFD Marine Laboratory, Aberdeen), were run as a reference control. The limit of detection for the assay was $50 \mathrm{pmol} \mathrm{min}^{-1} \mathrm{mg}^{-1}$ protein.

Statistical analysis. Variations in EROD activity attributable to site, season, temperature, conductivity and age were investigated using analysis of variance (ANOVA) on $\log _{\mathrm{e}}$-transformed data. Where an effect was observed, significant differences between means were determined using Tukey's pairwise comparisons.

\section{RESULTS}

Eels ranged between 184 and $790 \mathrm{~mm}$ in length $(8$ to $823 \mathrm{~g}$ wet weight), but the majority were less than $500 \mathrm{~mm}$. Otolith annuli showed the eels to be between 1 and $18 \mathrm{yr}$ old with a mean age of $7.37 \pm 0.23 \mathrm{yr}$. The majority of flounders were small $0+$ to $3+$ yr old individuals, between 50 and $224 \mathrm{~mm}$ in length ( 3 to $150 \mathrm{~g}$ ), but a few older $4+$ and $5+$ yr old individuals up to $392 \mathrm{~mm}$ (563 g) were also collected.

The monthly water temperature (calculated as the mean of daily values) at both sites showed similar pronounced seasonal variation (Fig. 2a). In 1996-97 and $1997-98$, minimum temperatures of 3 to $4^{\circ} \mathrm{C}$ were recorded in January and maximum temperatures of 19 to $21^{\circ} \mathrm{C}$ occurred in July and August.

S9 liver fractions contained between 1 and $5 \mathrm{mg}$ protein $\mathrm{ml}^{-1}$. In eels, EROD activity did not correlate with age $(p>0.05)$ or conductivity $(p>0.05)$ but correlated significantly $(p<0.001)$ with month of capture and tended to follow seasonal changes in water temperature (cf. Fig. 2a,b). Activity increased during the summer months and declined during the autumn and winter (Fig. 2b). Maximal activities were recorded in July 1996 and June 1997 (656 and $820 \mathrm{pmol} \mathrm{min}^{-1} \mathrm{mg}^{-1}$ protein respectively) and declined to $117-128 \mathrm{pmol} \mathrm{min}^{-1}$ $\mathrm{mg}^{-1}$ protein in December/January 1996 and to 307-362 $\mathrm{pmol} \mathrm{min}^{-1} \mathrm{mg}^{-1}$ protein in December/January 1997.

EROD activity in flounders from Oldbury also exhibited significant monthly variation $(p<0.001)$, but the pattern was more complex than observed for eels (Fig. 2c). Activity was lowest in May and June (84 to $190 \mathrm{pmol} \mathrm{min}^{-1} \mathrm{mg}^{-1}$ protein), but rose in July and August (470 to $650 \mathrm{pmol} \mathrm{min}{ }^{-1} \mathrm{mg}^{-1}$ protein). Unlike eels however, maximum activity occurred in the winter (e.g. March 1997; $1546 \mathrm{pmol} \mathrm{min}^{-1} \mathrm{mg}^{-1}$ protein). 

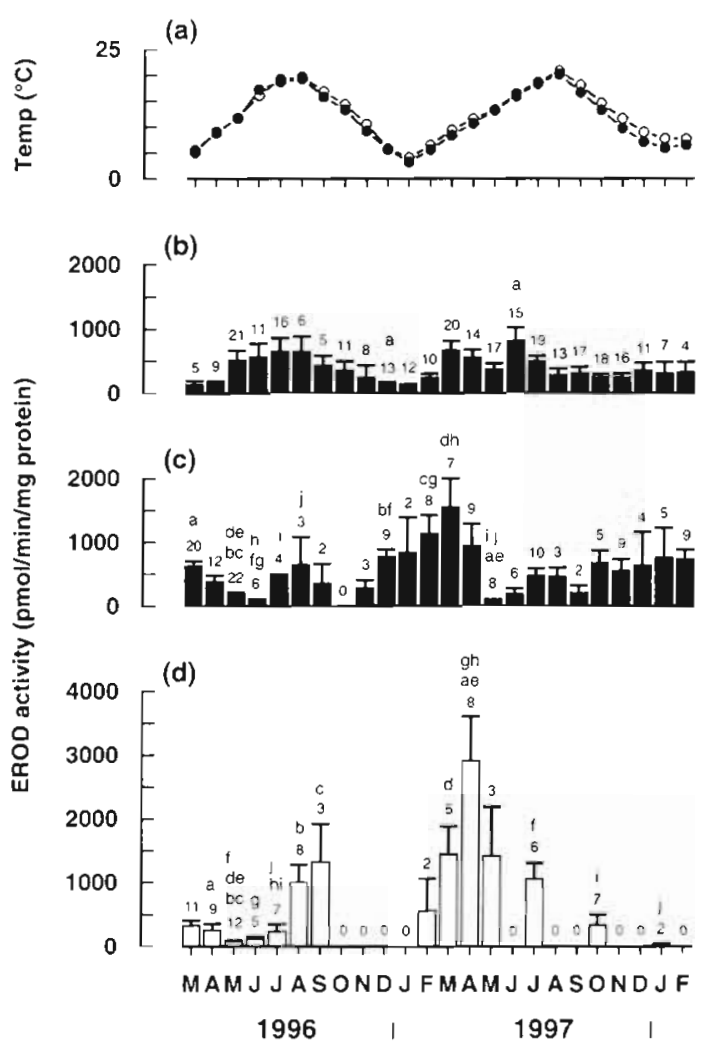

Fig. 2. (a) Monthly water temperature at Oldbury-upon-Severn ( ) and Hinkley Point (O). Temperatures are calculated from the mean daily temperature of the power station intakewater at each location. Hepatic EROD activity in (b) eels and (c) flounders from Oldbury (closed bars) and (d) flounders from Hinkley (open bars). Values are monthly means \pm 1 SEM with the number of fish in each sample given above each error bar. Pairs of letters indicate values that are significantly different $(p<0.001$; Tukey $)$

Although considerably fewer flounders were obtained from Hinkley, the month fish were captured at this site also significantly affected the EROD activity recorded $(p<0.001)$. The enzyme activity generally paralleled the pattern seen in fish from Oldbury, but with the seasonal cycle shifted by 1 to 2 mo later in the year (cf. Fig. 2c,d). Activity also tended to be 1.5- to 2.0-fold higher in flounders from Hinkley than in fish obtained at the same time of year from Oldbury, but the differences were not significant $(p>0.05)$.

When eels from Oldbury were held in laboratory aquaria for $5 \mathrm{wk}$, their mean liver EROD activity was 70 $\pm 20 \mathrm{pmol} \mathrm{min}^{-1} \mathrm{mg}^{-1}$ protein. This value is close to the minimum detection limit for the assay and lower than the minimum activity measured in fish taken directly from the estuary $\left(-120 \mathrm{pmol} \mathrm{min}^{-1} \mathrm{mg}^{-1}\right.$ protein; Fig. 2b). When fish were injected with $B[a] P$ (a relatively high dose designed to induce high EROD activity rather than to mimic actual environmental exposure), EROD activity increased significantly after $5 \mathrm{~d}$ ( $p<$ 0.001 ) to $2246 \pm 244 \mathrm{pmol} \mathrm{min}^{-1} \mathrm{mg}^{-1}$ protein. Likewise, flounders acclimated to clean estuarine water for $5 \mathrm{wk}$ had a mean EROD activity of $102 \pm 34 \mathrm{pmol}^{-1} \mathrm{~min}^{-1}$ $\mathrm{mg}^{-1}$ protein, a value similar to the lowest activity recorded in fish from the estuary at the same time of year. This increased significantly $(p<0.01)$, to $1128 \pm$ $346 \mathrm{pmol} \mathrm{min} \mathrm{mg}^{-1} \mathrm{mg}^{-1}$ protein $5 \mathrm{~d}$ after injection with $\mathrm{B}[\mathrm{a}] \mathrm{P}$, a level comparable to the maximum observed in fish assayed directly from the estuary (Fig. 2c,d).

In Fig. 3, mean EROD activities are shown for flounders of the same age caught during different seasons of the year. For Oldbury fish, the maximum EROD activity was observed in the winter and spring of each year (Fig. 3a). This was most evident in $3+$ fish, which had the highest EROD activities, but it was also apparent for $2+$ and $1+$ year classes and the differences between age categories were not significant $(p>0.05)$. Similar trends were apparent for Hinkley fish, but with peak activity occurring 1 season later in the year, i.e. spring and summer, for $1+$ and $2+$ fish (Fig. 3b).

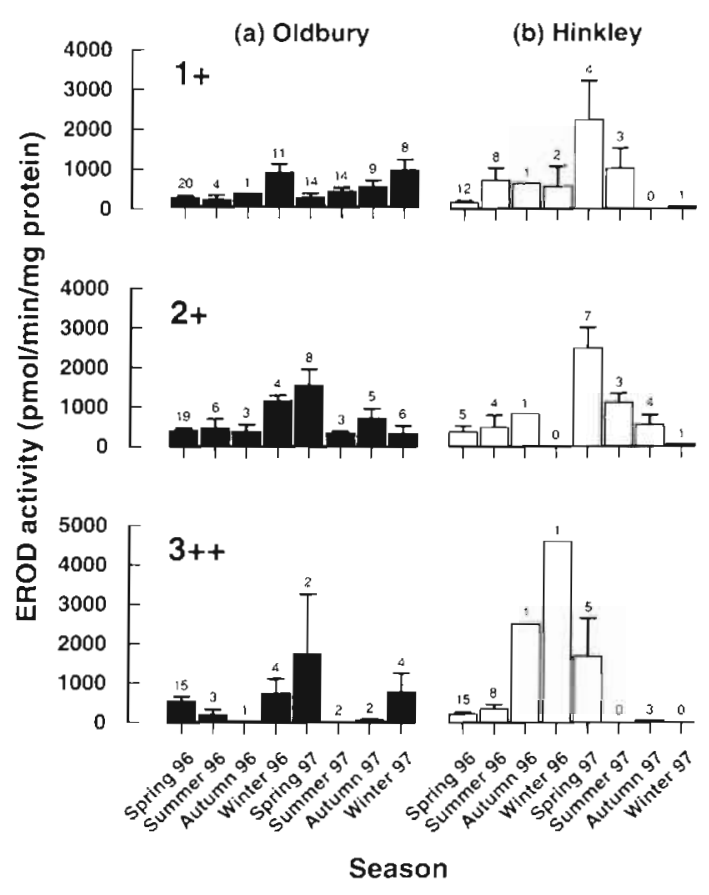

Fig. 3. Hepatic EROD activity in flounders of different ages from (a) Oldbury (closed bars) and (b) Hinkley (open bars). The $3++$ category includes some $4+$ and $5+$ fish. Values for each season are based on data pooled for consecutive $3 \mathrm{mo}$ periods and are means \pm 1 SEM. The number of fish in each sample is given above each error bar 


\section{DISCUSSION}

Although CYP1A activity has been commonly employed as a biomarker for several species of fish and in many different aquatic environments, it has not been previously reported for any fish species in the Severn Estuary or Bristol Channel. Despite its widespread use, little is known about the extent of natural variation and how this affects results from field studies. Our results show that EROD activity in 2 ecologically important species of estuarine fish exhibit marked seasonal fluctuations.

The seasonal pattern of EROD activity we observe might be expected as a direct consequence of the general increase in metabolic rate that is associated with increasing temperature in poikilotherms. Thus, in eels, minimum EROD activity occurred in the winter when the water temperature was below about $5^{\circ} \mathrm{C}$ and maximum levels were recorded in the summer when the temperature reached approximately $21^{\circ} \mathrm{C}$. Similar, but less pronounced variation in EROD activity was also seen in flounders especially in fish obtained during the summer of 1996 (Fig. 2c,d). The highest activity in flounders however, was observed between December and March and broadly coincided with the spawning period (February through May; Wheeler 1969) although other endogenous annual cycles may also be important (see below). In eels however, seasonal changes in EROD activity are not likely to be related to sexual maturation since they do not begin to mature until after they have entered their silver phase and migrated out of the estuary (Wheeler 1969, Moriarty 1978)

There are few long-term studies that have monitored seasonal variation in EROD activity in fish. Although Fenet et al. (1996) studied CYP1A activity in eels, seasonal effects were not investigated. Recently, Hylland et al. (1998) reported seasonal variation in several biomarkers over a single year for flounders (Table 1). Two other studies on flounders found no evidence for temperature-related increases (Eggens et al. 1995, 1996b; Table 1), but a positive correlation has been demonstrated for English sole Pleuronectes vetulus (Collier et al. 1995). However, in the dab Limanada limanda, maximum EROD activity was associated with minimum temperatures in the North Sea (Lange et al. 1992, Saborowski et al. 1996).

The increase in EROD activity associated with sexual maturity in fish is well established and has been correlated with plasma vitellogenin titres (Anderson et al. 1996, Janssen et al. 1997). Males frequently show higher activity than females, but differences between the sexes are not always apparent (Table 1). In the majority of flounders used in this study, the gonads were barely detectable and all the fish, except a few of the oldest individuals, were immature juveniles. Other workers have tried to avoid the complications that arise due to the effects of sexual maturation by selecting only immature fish. However, the data presented here for flounders of different ages (Fig. 3) imply that this may not eliminate such an interference. Even in 1+ fish, an elevation in EROD activity is observed in the winter and spring. This seasonal increase cannot be associated with increases in plasma titres of circulating reproductive hormones since there is no concomitant development of the gonads (Harmin et al. 1995, Sol et al. 1998). Nevertheless, the increases appear to be related to an endogenous annual cycle that is present even in very young fish and may be related to some other aspect of the physiology/endocrinology of flounders that is responding to changes in day length.

The seasonal variations described in this study may therefore be summarised in terms of 2 separate seasonal cycles. In eels, only 1 cycle is apparent, which appears to be related to seasonal changes in temperature. In flounders, the pattern suggests that 2 cycles are superimposed on one another. One cycle is a temperature-related phenomenon and the second, more dominant cycle, is associated with the reproductive or some other annual cycle.

EROD activity in eels and flounders, held in clean water for several weeks, was similar to the minimum recorded for these species processed immediately after collection from the estuary and this implies that the stress associated with capture did not seriously affect the measurements. Apart from the effect of natural seasonal cycles, the recorded EROD activities may partly be due to environmental contamination in the estuary, and the level of activity recorded over $2 \mathrm{yr}$ suggests that both eels and flounders are chronically exposed to low amounts of contamination. The levels recorded in flounders from the Severn Estuary are generally comparable with other studies on this species in European waters that are known to be contaminated (Table 1), and this suggests that at least some enzyme induction by xenobiotics had occurred.

Data on the level of sediment contamination in the estuary are quite limited, although 4 sites are routinely monitored as part of the National Monitoring Programme (Fig. 1). Most organic compounds measured in the sediment at these sites are below the limits

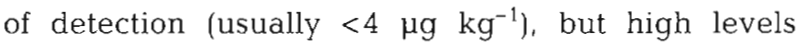
$\left(>100 \mu \mathrm{g} \mathrm{kg}^{-1}\right.$ ) of PCBs have been recorded at Peterstone Flats and Bedwin Sands that may be associated with a known point source in the estuary or result from past historical contamination (Davies 1996). In general, however, the estuary apparently contains low levels of a cocktail of organic compounds that emanate from multiple sewage and industrial discharge sites and no seasonal cycles of contamination have been identified. 
Table 1. Platichthys flesus. Hepatic EROD activity recorded in European flounders P. flesus in recent laboratory and field investigations. Only studies where observations on the effects of season, sex, sexual maturity age or temperature have been included

\begin{tabular}{|c|c|c|c|c|}
\hline Site/conditions & Inducer(s) & $\begin{array}{l}\text { EROD activity } \\
\text { pmol min-1 mg-1 } \\
\text { protein) }\end{array}$ & Notes & Source \\
\hline Laboratory induction & PCBs & Range: 4 to 23 & $\begin{array}{l}\text { Conducted Jun } \\
\text { Fish 'about' 2+ }\end{array}$ & Basselink et al. (1996) \\
\hline $\begin{array}{l}\text { Caging in Norwegian } \\
\text { fjord }\end{array}$ & PAHs and PCBs & Range: 4 to 39 & $\begin{array}{l}\text { Conducted Aug to Nov } \\
\text { Male or immature fish }\end{array}$ & Beyer et al. (1996) \\
\hline Laboratory induction & i.m. $\mathrm{B}[a] \mathrm{P} \& \mathrm{PCBs}$ & $\begin{array}{l}\text { Control: } 50 \\
\text { Induced: } 650\end{array}$ & $\begin{array}{l}\text { Time response Jun } \\
\text { Dose response Oct/Nov } \\
\text { Maximum induction in } 4 \text { to } 8 \mathrm{~d} \text {. }\end{array}$ & Beyer et al (1997) \\
\hline North Sea & PAHs and PCBs & Range: 3 to 172 & $\begin{array}{l}\text { Maximum activity in summer } \\
\text { No correlation with temperature } \\
\text { No sex differences }\end{array}$ & Eggens et al. (1995) \\
\hline $\begin{array}{l}\text { Mesocosm exposure } \\
6 \text { to } 24 \mathrm{mo}\end{array}$ & Harbour sediments & $\begin{array}{l}\text { Reference: } 30 \text { to } 174 \\
\text { Exposed: } 25 \text { to } 169\end{array}$ & Males > females & Eggens et al. (1996a) \\
\hline Laboratory induction & $\begin{array}{l}\text { i.p. B }[a] \text { P up to } \\
12.5 \mathrm{mg} \mathrm{kg}^{-1}\end{array}$ & $\begin{array}{l}\text { Control: } 20 \text { to } 80 \\
\text { Induced: } 420 \text { to } 1420\end{array}$ & & Eggens et al. (1996a) \\
\hline $\begin{array}{l}\text { Dutch Wedden Sea, } \\
\text { Netherlands }\end{array}$ & Various & Range: 100 to 1400 & $\begin{array}{l}\text { Maximum activity Mar/Apr } \\
\text { at spawning } \\
\text { No correlation with temperature } \\
\text { Males > females }\end{array}$ & Eggens et al. (1996b) \\
\hline $\begin{array}{l}\text { Severn Estuary, } \\
\text { England }\end{array}$ & Various & Range: 84 to 1546 & $\begin{array}{l}\text { Minimum activity summer } \\
\text { Maximum activity winter } \\
\text { spring } \\
\text { No effect of age }(0+\text { to } 3++)\end{array}$ & $\begin{array}{l}\text { Rotchell et al. } \\
\text { (this study) }\end{array}$ \\
\hline Laboratory induction & i.p. B $|a| \mathrm{P} 100 \mathrm{mg}$ & $\begin{array}{l}\text { Control: } 102 \\
\mathrm{~kg}^{-1}\end{array}$ & $\begin{array}{l}\text { Measured after } 5 \alpha \\
\text { Induced: } 1128\end{array}$ & $\begin{array}{l}\text { Rotchell et al. } \\
\text { (this study) }\end{array}$ \\
\hline $\begin{array}{l}\text { Forth Estuary, } \\
\text { Scotland }\end{array}$ & $\begin{array}{l}\text { PAHs and petro- } \\
\text { chemicals }\end{array}$ & $\begin{array}{l}\text { Range: } 9200 \text { to } \\
32600 \text { (pmol g }{ }^{-1} \text { liver) }\end{array}$ & $\begin{array}{l}\text { Conducted Sep } \\
\text { 'Immature' } 1+\text { to } 3+\text { fish }\end{array}$ & Sulaiman et al. (1991) \\
\hline
\end{tabular}

While it was not an objective of this study to determine which compound(s) might contribute to the observed EROD activity recorded in eels and flounders, the fact that high PAH and PCB levels have been recorded in some sediments may be significant.

In this paper we have shown that the pronounced seasonal variation in EROD activity that occurs in flounders, and to a lesser extent in eels, is considerably greater than the elevations that may be related to chronic environmental contamination in the Severn Estuary. The winter/spring elevations in EROD activity in flounders, which are probably related to reproductive or other annual cycles, are of some concern because they are detectable even in very young fish. Eel EROD activity however, shows a predictable seasonal pattern, and this species may be better suited for monitoring the effects of contamination in fish from estuarine environments.
Acknowledgements. Our gratitude is expressed to D. Molesworth, J. Drew and G. Freeman, who helped with the collection of animals, and to staff at Oldbury-upon-Severn and Hinkley Point power stations for their assistance and cooperation. We would also like to thank C. Jackson for preparing Fig. 1. An Institutionai Grant from The Leverhulme Trust funded this study.

\section{LITERATURE C:ITED}

Anderson MJ, Miller MR, Hinton DE (1996) In vitro modulation of $17 \beta$ estradiol-induced vitellogenin synthesis: effects of cytochrome P4501A.1 inducing compounds on rainbow trout (Oncorhynchus mykiss) liver cells. Aquat Toxicol 34:327-350

Anonymous (1997) Severn Estuary. Joint issues report of The Severn Estuary Strategy, University of Wales. Environment Agency, Cardiff

Basselink HT, van Beusekom S, Roex E, Vethaak AD, Koeman $\mathrm{JH}$, Brouwer A (1996) Low hepatic 7-ethoxyresorufin- $O$ deethylase (EROD) activity and minor alterations in re- 
tinoid and thyroid hormone levels in flounder (Platichthys flesus) exposed to the polychlorinated biphenyl (PCB) mixture, clophen A50. Environ Pollut 92:267-274

Beyer J, Sandvik M. Hylland K, Fjeld E, Egaas E, Aas E, Skåre JU, Goksøyr A (1996) Contaminant accumulation and biomarker responses in flounder (Platichthys flesus L.) and Atlantic cod (Gadus morhua L.) exposed by caging to polluted sediments in Sørfjorden, Norway. Aquat Toxicol 36:75-98

Beyer J, Sandvik M, Skåre JU, Egaas E, Hylland K, Waagbø R, Goksøyr A (1997) Time- and dose-dependent biomarker responses in flounder (Platichthys flesus L.) exposed to benzo[a]pyrene, 2,3,3',4,4',5-hexachlorobiphenyl (PCB-156) and cadmium. Biomarkers 2:35-44

Burke MD, Mayer RT (1974) Ethoxyresorufin: direct fluorimetric assay of microsomal O-dealkylation which is preferentially inducible by 3-methylcholanthrene. Drug Metab Dispos 2:583-588

Christensen JM (1964) Burning of otoliths, a technique for age determination of soles and other fish. $J$ Cons Int Explor Mer 29:73-81

Collier TK, Anulacion BF, Stein JE, Goksøyr A, Varanasi U (1995) A field evaluation of cytochrome P4501A as a biomarker of contaminant exposure in three species of flatfish. Environ Toxicol Chem 14:143-152

Curtis LR, Carpenter HM, Donohoe RM, Williams DE, Hedstrom OR, Delnzer ML, Beilstein MA, Foster $E_{1}$ Gates R (1993) Sensitivity of cytochrome P450-1A1 induction in fish as a biomarker for distribution of TCDD and TCDF in the Willamette River, Oregon. Environ Sci Technol 27 $2149-2157$

Davies G (1996) Severn Estuary catchment management plan data analysis. Environment Agency Technical Memorandum EAU/96/12, Environment Agency. Bath

de Boer J, Hagel P (1994) Spatial differences and temporal trends of chlorobiphenyls in yellow eel (Anguilla anguilla) from inland waters of the Netherlands. Sci Total Environ 141:155-174

Eggens $M$, Bergman $A$, Vethaak $D$, van der Weiden $M$, Celander M, Boon JP (1995) Cytochrome P4501A indices as biomarkers of contaminant exposure: results of a field study with plaice (Pleuronectes platessa) and flounder (Platichthys flesus) from the southern North Sea. Aquat Toxicol 32:211-225

Eggens ML, Vethaak AD, Leaver MJ, Horbach GJMJ, Boon JP, Seinen W (1996a) Differences in CYP1A response between flounder (Platichthys flesus) and plaice (Pleuronectes platessa) after long-term exposure to harbour dredged spoil in a mesocosm study. Chemosphere 32: $1357-1380$

Eggens ML, Opperhuizen A, Boon JP (1996b) Temporal variation of CYP1A indices, $\mathrm{PCB}$ and 1-OH pyrene concentration in flounder, Platichthys flesus, from the Dutch Wadden Sea. Chemosphere 33:1579-1596

Fenet $\mathrm{H}$, Casellas $\mathrm{C}$, Bontoux $J$ (1996) Hepatic enzymatic activities of the European eel Anguilla anguilla as a tool for biomonitoring freshwater streams: laboratory and field caging studies. Water Sci Technol 33:321-329

Förlin L, Andersson T, Balk L, Larsson $\AA$ (1995) Biochemical and physiological effects in fish exposed to bleached kraft mill effluents. Ecotoxicol Environ Saf 30:164-170

George SG, Wright J, Conroy J (1995) Temporal studies of the impact of the Braer oilspill on inshore feral fish from Shetland, Scotland. Arch Environ Contam Toxicol 29:530-534

Goksøyr A, Förlin L (1992) The cytochrome P-450 system in fish, aquatic toxicology and environmental monitoring. Aquat Toxicol 22:287-312
Goksøyr A, Beyer J, Egaas E, Grøsvik BE. Hylland K, Sandvik M. Skaare JU (1996) Biomarker responses in flounder (Platichthys flesus) and their use in pollution monitoring Mar Pollut Bull 33:36-45

Harmin SA, Crim LW, Wiegand MD (1995) Plasma sex steroid profiles and the seasonal reproductive cycle in male and female winter flounder, Pleuronectes americanus. Mar Biol 121:601-610

Huuskonen S, Lindström-Seppä P (1995) Hepatic cytochrome P4501A and other biotransformation activities in perch (Perca fluviatilis): the effects of unbleached pulp mill effluents. Aquat Toxicol 31:27-41

Hylland $K$, Sandvik M, Utne Skåre J, Beyer J, Egaas E, Goksoyr A (1996) Biomarkers in flounder (Platichthys flesus). an evaluation of their use in pollution monitoring. Mar Environ Res 42:223-227

Hylland K, Nissen-Lie T, Christensen PG, Sandvik M (1998) Natural modulation of hepatic metallothionein and cytochrome P4501A in flounder, Platichthys flesus L. Mar Environ Res 46:51-55

Janssen PAH, Lambert JGD, Vethaak AD, Goos HJT (1997) Environmental pollution caused elevated concentrations of oestradiol and vitellogenin in the female flounder, Platichthys flesus (L.). Aquat Toxicol 39:195-214

Lange UWE, Jedamski-Grymlas J, Siebers D, Karbe L (1992) Ethoxyresorufin O-deethylase and cytochrome P450 in the liver of dab (Limanda limanda (L.)) from the central and southern North Sea. Mar Pollut Bull 24 $446-451$

Law RJ, Biscaya JL (1994) Polycyclic aromatic hydrocarbons (PAH) - problems and progress in sampling, analysis and interpretation. Mar Pollut Bull 29:235-241

Law RJ, Dawes VJ, Woodhead RJ, Matthiessen P (1997) Polycyclic aromatic hydrocarbons (PAH) in seawater around England and Wales. Mar Pollut Bull 34:306-322

Lindström-Seppä P (1985) Seasonal variation of the xenobiotic metabolizing enzyme activities in the liver of male and female vendance (Coregonus albula L.). Aquat Toxicol 6: $323-331$

Lindström-Seppä $P$, Huuskonen S, Pesonen M, Muona $P$, Hänninen $O$ (1992) Unbleached pulp mill effluents affect cytochrome P450 monooxygenase enzyme activities. Mar Environ Res 34:157-161

Livingstone DR (1993) Biotechnology and pollution monitoring: use of molecular biomarkers in the aquatic environment. J Chem Technol Biotechnol 57:195-211

Moriarty C (1973) A technique for examining eel otoliths J Fish Biol 5:183-184

Moriarty C (1978) Eels, a natural and unnatural history. Douglas David \& Charles Ltd, Vancouver

Murphy DL, Gooch JW (1997) EROD and CYP1A protein in channel catfish (Ictalurus punctatus) from an urban estuary relative to that in benzo[a|pyrene-exposed hatchery specimens. Environ Pollut 95:235-239

Narbonne JF, Garrigues P, Ribera D, Raoux C, Mathieu A. Lemaire $P$, Salaun JP, Lafaurie M (1991) Mixed-function oxygenase enzymes as tools for pollution monitoring: field studies on the French coast of the Mediterranean Sea Comp Biochem Physiol 100C:37-42

Saborowski R, Lange U, Buchholz F (1996) Natural variability of hepatic cytochrome P450 1A activity in North Sea dab (Limanda limanda). Zeit Angew Zool 81:73-83

Sleiderink HM, Oostingh I, Goksøyr A, Boon JP (1995) Sensitivity of cytochrome P450 1A induction in dab (Limanda limanda) of different age and sex as a biomarker for environmental contaminants in the southern North Sea. Arch Environ Contam Toxicol 28:423-430 
Sol SY, Olson OP, Lomax DP, Johnson LL (1998) Gonadal development and associated changes in plasma reproductive steroids in English sole. Pleuronectes vetulus, from Puget Sound, Washington. Fish Bull 96:859-870

Stagg R, Mclntosh A, Mackie P (1995) Elevation of hepatic monooxygenase activity in the dab (Limanda limanda) in relation to environmental contamination with petroleum hydrocarbons in the northern North Sea. Aquat Toxicol 33:245-264

Stegeman JJ, Hahn ME (1994) Biochemistry and molecular biology of monooxygenases: current perspectives on forms, functions, and regulation of cytochrome $\mathrm{P} 450$ in aquatic species. In: Malins DC, Ostrander GK (eds) Aquatic toxicology: molecular, biochemical and cellular perspectives. CRC Press, Boca Raton, FL, p 87-206

Sulaiman N, George S, Burke MD (1991) Assessment of sub-

Editorial responsibility: Otto Kinne (Editor)

Oldendorf/Luhe, Germany lethal pollutant impact on flounders in an industrialised estuary using hepatic biochemical indices. Mar Ecol Prog Ser 68:207-212

Vandermeulen JH, Mossman D (1996) Sources of variability in seasonal hepatic microsomal oxygenase activity in winter flounder (Pleuronectes americanus) from a coal tar contaminated estuary. Can J Fish Aquat Sci 53:1741-1753

van der Oost R, Goksøyr A, Celander M, Heida H, Vermeulen NPE (1996) Biomonitoring aquatic pollution with feral eel (Anguilla anguilla). II. Biomarkers: pollution-induced biochemical responses. Aquat Toxicol 36:189-222

Weatherley NS, Davies GL, Ellery S (1997) Polychlorinated biphenyls and organochlorine pesticides in eels (Anguilla anguilla L.) from Welsh rivers. Environ Pollut 95:127-134

Wheeler A (1969) The fishes of the British Isles and northwest Europe. Macmillan, London

Submitted: March 26, 1999; Accepted: July 7, 1999

Proofs received from author(s): November 11, 1999 